PRACE NAUKOWE UNIWERSYTETU EKONOMICZNEGO WE WROCLAWIU

Nauki ekonomiczne w XXI wieku - wyzwania, dylematy, perspektywy

Ekonomia, finanse, nauki o zarządzaniu

ISSN 1899-3192

e-ISSN 2392-0041

\title{
Zbigniew Bentyn
}

Uniwersytet Ekonomiczny w Poznaniu

e-mail: zbigniew.bentyn@ue.poznan.pl

\section{POTENCJALNY WPEYW BREXITU \\ NA ZMIANĘ WYDAJNOŚCI LOGISTYCZNEJ \\ ZJEDNOCZONEGO KRÓLESTWA}

\section{POTENTIAL IMPACT OF BREXIT \\ ON CHANGE OF LOGISTIC PERFORMANCE OF THE UNITED KINGDOM}

DOI: $10.15611 /$ pn.2017.499.02

JEL Classification: F23, M16

Streszczenie: Gospodarka Unii Europejskiej wpływa na konfigurację łańcuchów dostaw powstających na jej obszarze. Zmiany, które dotyczą dostępu do jej obszaru, w konsekwencji wpływają na wydajność logistyczną przedsiębiorstw w łańcuchach dostaw. Celem opracowania jest wskazanie kierunków potencjalnych zmian w obszarze funkcjonowania europejskich łańcuchów dostaw następujących w kontekście realizacji Brexitu. Wykorzystując analizę danych dotyczących indeksu Logistics Performance Index, przedstawiono dotychczasowy rozwój wydajności logistycznej Zjednoczonego Królestwa w czasie i porównano go do zmian wydajności w regionie Europa-Centralna Azja. Porównanie zmian tego wskaźnika umożliwia wnioskowanie o korzystnym wpływie realizacji dotychczasowej polityki integracji na wydajność logistyczną. Rozpoczęcie procesu Brexitu może jednak zakłócić dotychczasową tendencję wzrostową ze względu na powstanie barier w dostępie do wspólnego europejskiego rynku.

Słowa kluczowe: wydajność logistyczna, europejskie łańcuchy dostaw, logistyka międzynarodowa.

Summary: The EU's economy influences the configuration of the supply chains in its area. Changes that affect access to the area affect the logistics performance of enterprises in the supply chains as a consequence. The aim of the study is to identify potential directions for changes in the functioning of the European supply chains in the context of the implementation of Brexit. Using the Logistic Performance Index data analysis it is explained that UK's logistical performance corelates with performance changes in Europe and the Central Asian region. The comparison of changes in this indicator makes it possible to deduce the positive impact of the implementation of the current integration policy on logistic performance. The start of the Brexit process may, however, disrupt the current upward trend due to barriers to access to the single European market.

Keywords: logistics performance, European supply chains, international logistics. 


\section{Wstęp}

Europejskie łańcuchy dostaw ulegały ewolucji wraz z rozwojem terytorium UE. Dzięki kolejnym akcesjom potencjał gospodarczym Unii rósł podobnie, jak i rynek wymagający obsługi logistycznej. Dzięki wieloletnim więziom gospodarczym w centralnej części Europy Zachodniej ukształtował się region szczególnej aktywności logistycznej nazywany z racji swojego kształtu Blue Banana [Gorzelak 2012]. Ten obszar łączący północne Włochy przez terytoria Niemiec, Francji i Holandii zawiera także północną część obszaru Zjednoczonego Królestwa. W wyniku intensywnej współpracy gospodarczej powstały więzi gospodarcze między podmiotami zlokalizowanymi w tym obszarze. W efekcie rozwoju technologii oraz modernizacji procesów wytwarzania rosły także wymagania w stosunku do obsługujących je operatorów logistycznych. Jednocześnie dzięki likwidacji kolejnych barier dzięki prawodawstwu UE zmierzającemu w kierunku swobody przepływu ludzi, towarów i kapitału uzyskano warunki do redukcji kosztów logistycznych poprzez usprawnioną strukturę i organizację procesów logistycznych. W efekcie rosnąca wydajność logistyczna poszczególnych państw UE, w tym wymienionych wcześniej, tworzących obszar Blue Banana, umożliwiała integrację ogniw europejskich łańcuchów dostaw na wysokim, światowym poziomie. Jednak od 29 marca 2017 r., od kiedy uruchomiono procedurę wyjścia z UE według artykułu 50 Traktatu lizbońskiego, podmioty gospodarcze zintegrowane w europejskich łańcuchach dostaw będą zmuszone przygotować się do zmian wpływających na tempo i elastyczność dostaw.

Celem opracowania jest wskazanie kierunków potencjalnych zmian w obszarze funkcjonowania europejskich łańcuchów dostaw następujących w kontekście realizacji Brexitu. Dzięki przedstawieniu dotychczasowej pozytywnej korelacji między wzrostem wydajności logistycznej Zjednoczonego Królestwa a obszarem Europy i Azji Centralnej oraz opisaniu potencjalnych zagrożeń dla poszczególnych czynników kształtujących wydajność logistyczną można zarysować perspektywę zmian w obszarze wydajności logistycznej po opuszczeniu unii celnej przez Zjednoczone Królestwo. Służy to także sformułowaniu wskazań dla łańcuchów dostaw mających na celu podtrzymanie wysokiego poziomu obsługi logistycznej pomimo przewidywanych zmian prawnych i gospodarczych.

\section{Europejskie lańcuchy dostaw}

Rozwój UE w wymiarze przestrzennym odbywał się przez kolejne integracje krajów aspirujących do członkostwa. Istniejące łańcuchy dostaw ulegały adaptacji w taki sposób, aby przy jednoczesnym minimalizowaniu kosztów logistycznych rozbudowywać sieć dystrybucji obejmującą nowe obszary. Upływające lata współpracy podmiotów gospodarczych krajów członkowskich w obrębie UE skutkowały rosnącą wydajnością logistyczną danych regionów. Dzięki utworzeniu Europejskiej Wspólnoty Węgla i Stali kraje założyciele, czyli Belgia, Francja, Luksemburg, Holandia, 
Niemcy i Włochy, są obecnie liderami światowego rankingu wydajności logistycznej indeksowanego przez Bank Światowy. Kolejne grupy krajów uzyskujące akcesje do UE otrzymują odpowiednio gorsze uśrednione wyniki wskaźnika LPI (Logistic Performance Index). Dłuższy czas upływający od akcesji do UE jest silnie pozytywnie skorelowany z uśrednionymi indexami LPI krajów należących do danej grupy akcesyjnej. Zjednoczone Królestwo, nalężące do pierwszej grupy akcesyjnej (po grupie krajów założycieli) wraz z Danią i Irlandią, w roku 2014 zanotowało uśredniony indeks mLPI równy 3,89, a od czasu akcesji upłynęło wówczas 41 lat [Gołembska, Majchrzak-Lepczyk, Bentyn 2015, s. 65]. W najnowszym rankingu Banku Światowego grupa tych państw powtarza wynik z poprzedniego pomiaru mimo wahań w obrębie danych krajów. Zjednoczone Królestwo notuje wzrost LPI z 4,01 w roku 2014 do 4,07 w roku 2016 [lpi.worldbank.org].

Wdrażanie polityki integracji między krajami UE prowadzi do likwidacji barier i ułatwiania przepływu osób, towarów i kapitału. Osiągniecie tak określonego celu związane jest z likwidacją procedur celnych, usunięciem konieczności oczekiwania na granicach państwowych, a także poprawą infrastruktury transportowej i logistycznej [Van Goor, Ploos van Amstel 2003, s. 26]. Skoro celem głównym jest zwiększanie spójności poszczególnych regionów Europy, to europejskie łańcuchy dostaw są głównym beneficjentem programów inwestycyjnych skupionych na poprawie infrastruktury transportowej. Szybkie i elastyczne powiazania między ogniwami łańcuchów dostaw są koniecznością w zmiennych warunkach dzisiejszej gospodarki rynkowej. Dzięki programowi rozbudowy korytarzy transportu łączących Europę możliwe jest racjonalizowanie konfiguracji łańcuchów dostaw. Polega ono na redukcji liczby magazynów na rzecz wzrostu ich rozmiaru oraz usprawnień jakościowych związanych z uzyskiwanymi korzyściami skali. Budowa paneuropejskich centrów dystrybucji umożliwia wraz z dostępną siecią europejskich korytarzy transportu szybkie i efektywne kosztowo, dystrybuowanie towarów bez koniecznego jak wcześniej magazynowania lokalnego. Magazynowanie takie szeroko krytykowane w literaturze zwiększało koszty logistyczne i ryzyko utracenia przydatności sprzedażowej produktu.

Wspieranie rozwoju transportu i logistyki w UE, realizowane dzięki wspomnianym inwestycjom, dokonuje się także przez deregulację rynku usług transportowych. Trend ten jest wykorzystywany przez operatorów logistycznych zdolnych do konkurowania w procesie logistycznej obsługi klienta [Bentyn, Majchrzak-Lepczyk 2016, s. 275]. Ponadto rozwój gospodarki elektronicznej i jej wpływ na zmiany funkcjonowania handlu rewolucjonizuje relacje w ramach łańcuchów dostaw. Jest on powodem poszukiwania wysokiej jakości świadczonej obsługi logistycznej, bez której trudno konkurować na wymagającym europejskim rynku. Wymienione uwarunkowania i kierunki rozwoju europejskich łańcuchów dostaw wywierają nacisk i wywołują następujące reakcje w łańcuchach dostaw [Witkowski 2010, s. 2015]:

1. Powstawanie Europejskich Centrów Dystrybucji.

2. Kreowanie nowych konfiguracji sieci dostaw.

3. Ewolucja roli małych i średnich przedsiębiorstw. 
4. Poprawa jakości obsługi dostaw.

5. Rozwój outsourcingu i ekologii.

6. Rozwój przewozów multimodalnych.

Konsekwencja tych zmian są szybsze, tańsze i lepiej zarządzane łańcuchy dostaw wpływające korzystnie na integrację przedsiębiorstw w Europie. Ponadto, jak zauważył Blaik, kraje znajdujące się wysoko w rankingu wydajności logistycznej LPI jednocześnie charakteryzują się niskimi relatywnymi kosztami logistyki. Zależność ta działa także odwrotnie, tzn. niski poziom wydajności logistycznej oznacza zwykle wyższe koszty logistyczne [Blaik 2016, s. 59].

\section{Wydajność logistyczna w Zjednoczonym Królestwie}

Obecność Zjednoczonego Królestwa w pierwszej grupie akcesyjnej do UE oznacza, że powiązania gospodarcze między podmiotami gospodarczymi znajdującymi się zarówno na kontynencie, jak i na Wyspach Brytyjskich wykorzystują uprzywilejowane warunki wymiany towarowej już od 44 lat. Jest to najdłuższy okres kształtowania europejskich łańcuchów dostaw zaraz po krajach założycielach UE. Przedstawienie postępu, jaki Zjednoczone Królestwo uczyniło w pogłębianiu wydajności logistycznej, jest możliwe dzięki kolejnym badaniom prowadzonym przez Bank Światowy. Dane odnośnie do wydajności logistycznej w latach poprzedzających 2007 rok nie są dostępne. Najwcześniejszy pomiar Banku Światowego odbył się w roku 2007. Zmiany w zakresie współczynnika LPI, zmierzone w okresie 2007 do 2016, oznaczają wzrost wskaźnika z 3,99 do 4,07.

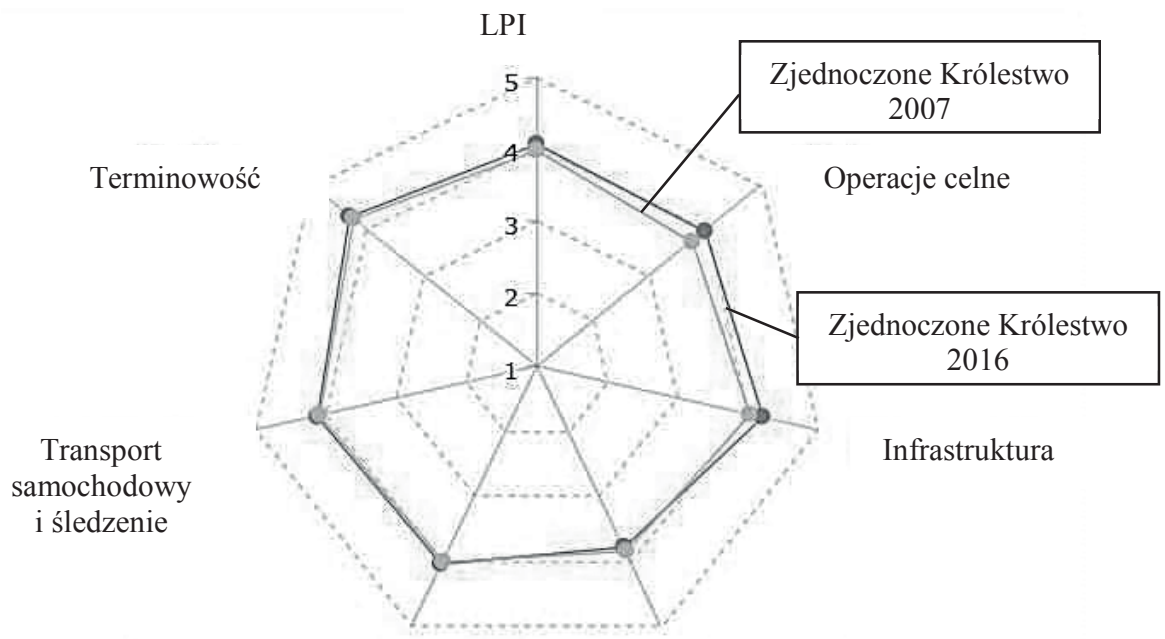

Kompetencje logistyczne

Przesyłki międzynarodowe

Rys. 1. Wykres zmiany współczynnika LPI Zjednoczonego Królestwa w latach 2007-2016

Źródło: [lpi.worldbank.org]. 
Zauważalna zmiana na korzyść dokonała się głównie w zakresie realizacji operacji celnych oraz infrastruktury. Zmiany w obszarach terminowości, transportu samochodowego oraz kompetencji logistycznych są już dużo mniejsze. Jedynie w odniesieniu do realizacji przesyłek międzynarodowych nastąpił niewielki spadek wydajności. Należy zauważyć, że od samego początku badania pomiarów wydajności logistycznej Zjednoczone Królestwo cechuje wysoki poziom tego wskaźnika. Niewątpliwie wieloletnia przynależność do obszaru szczególnej aktywności wytwórczej i logistycznej w Europie jest przyczyną wysokiego poziomu tego wskaźnika. Pomimo lat doświadczeń i wysokiego poziomu bazowego wydajności, w ostatnim badanym okresie pomiarowym wskaźnik wzrósł, udowadniając kompetencje logistyczne tego regionu.

Aby zobrazować zmiany w wydajności logistycznej Zjednoczonego Królestwa i porównać je ze zmieniającym się wskaźnikiem LPI w czasie, z regionu Europy i Azji Centralnej przedstawiono rys. 2. Zauważalna jest korelacja między wzrostem wskaźników badanych regionów.

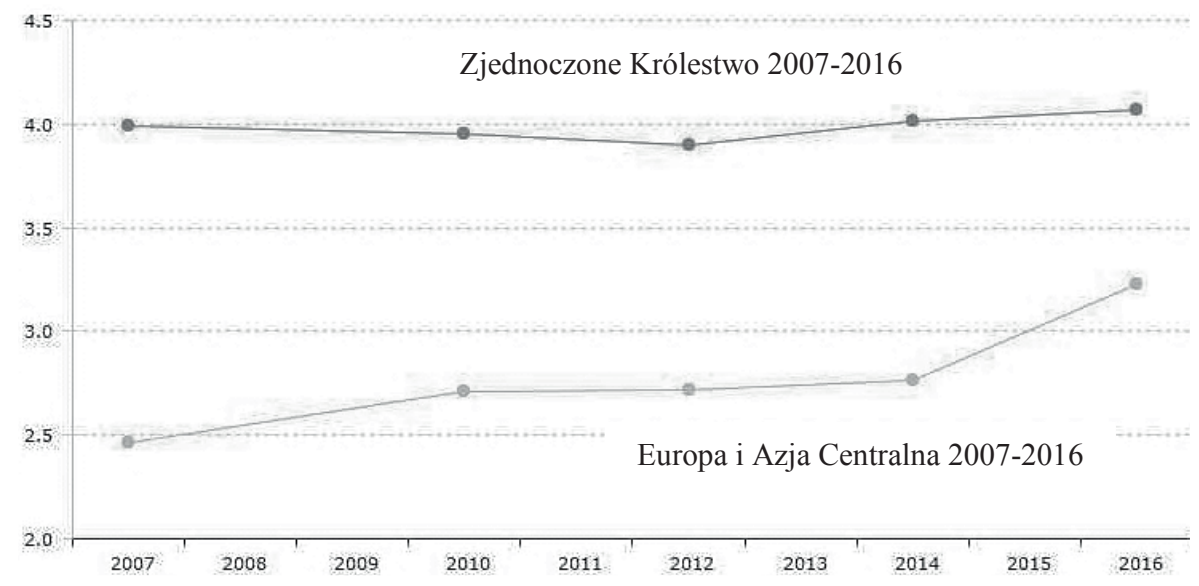

Rys. 2. Wykres korelacji zmian współczynników LPI Zjednoczonego Królestwa i regionu Europy i Azji Centralnej

Źródło: [lpi.worldbank.org].

Pomiar korelacji współczynnikiem Pearsona wyniósł $r=0,62$, a więc ujawnił dodatnią zależność między współczynnikiem LPI Zjednoczonego Królestwa a współczynnikiem LPI regionu Europy i Azji Centralnej. Siła tej zależności jest umiarkowana, o czym świadczy umieszczenie wyniku w przedziale [0,4-0,7]. Dowodzi on pozytywnego powiazania zmian wydajności logistycznej obu regionów. Przyczynami takiego stanu rzeczy mogą być wieloletnie powiązania gospodarcze podmiotów Zjednoczonego Królestwa z obszarem Europy. Są one szczególnie istotne dla wspominanego już obszaru szczególnej aktywności logistycznej Blue Banana. Niewątpliwie Zjednoczone Królestwo odgrywa także ważną rolę dla pozostałych 
kluczowych gospodarek UE jako obszar gromadzący podmioty gospodarcze skupione na wytwarzaniu i dostawach produktów wysokospecjalistycznych na potrzeby kontynentalnych odbiorców.



Rys. 3. Mapa geografii ekonomicznej Europy z zaznaczonym obszarem Blue Banana według Schatzla Źródło: [Schatzl 1993].

Zaznaczone na rys. 3 linie przerywane oddzielają obszary peryferyjne o niewielkim oddziaływaniu gospodarczym od regionu centralnego przypominającego kształtem owoc bananowca. Wizja ta uległa jednak zmianie wraz z kolejnymi aneksjami rozwijającymi UE terytorialnie w kierunku wschodnim i południowym. Analizy obszaru aktywności gospodarczej Europy trwały i polegały na ocenie wpływu czynników społecznych, politycznych, i gospodarczych [Bentyn 2016]. Zawsze jednak Zjednoczone Królestwo pozostawało w obszarze szczególnej aktywności gospodarczej. Regiony wokół dużych aglomeracji, jak Londyn i Birmingham, tworzą huby dystrybucyjne zaopatrujące zlokalizowane oddziały i znanych europejskich i światowych firm - rys. 4. Porty, jak np. szósty najszybciej rosnący port na świecie Southampton oraz ważne porty w Londynie i Felixtowe, zapewniają sprawne przepływy towarów drogą morską. Również europejski korytarz transportu TEN-T Morze Północne-Morze Śródziemne zapewnia sprawny transport drogowy i kolejowy. Połączenie Dover-Calais jest krytycznym dla sieci dostaw ogniwem spajających gospodarkę Zjednoczonego Królestwa z Europą kontynentalną. 


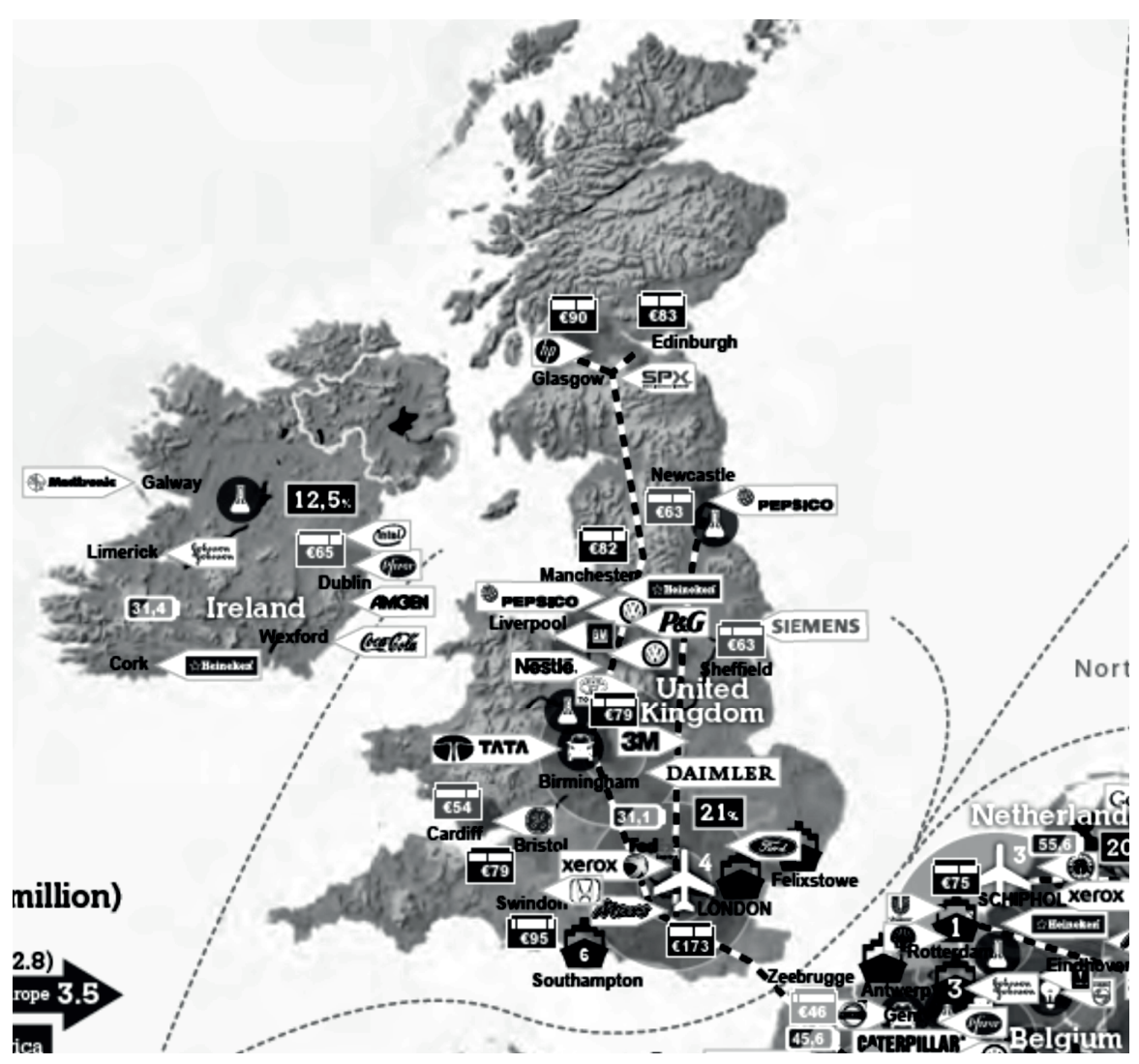

Rys. 4. Mapa łańcuchów dostaw w Zjednoczonym Królestwie SCM 2014/15

Źródło: [Supply Chain Media BV 2014].

\section{Zagrożenia dla wydajności logistycznej Zjednoczonego Królestwa w wyniku Brexitu}

Zakładając, że Zjednoczone Królestwo, decydując się na opuszczenie UE, jednocześnie opuszcza europejski obszar celny powołany w celu obsługi wspólnego europejskiego rynku. Należy rozważyć konsekwencje takiego działania dla wydajności logistycznej. Należy wskazać, że potencjalne problemy występujące przez powstanie nowych barier wstrzymujących przepływ towarów będą oddziaływać zarówno na podmioty gospodarcze na Wyspach Brytyjskich, jak i na ich partnerów w europejskich łańcuchach dostaw na kontynencie. Analizę potencjalnych problemów można przeprowadzić względem częściowych wskaźników wydajności logistycznej, na podstawie których budowany jest indeks główny. 
Należą do nich:

1. Zrozumiałość systemu celnego, szybkość obsługi celnej i przewidywalność formalności wykonywanych przez agencje obsługi celnej (customs).

2. Infrastruktura logistyczna w tym transportowa wspierająca operacje handlowe (infrastructure).

3. Latwość organizowania wysyłki ładunku w transporcie międzynarodowym (international shipment).

4. Jakość i kompetencje operatorów logistycznych (logistic competence).

5. Zdolność do identyfikacji i śledzenia przesyłek (tracking and tracing).

6. Częstotliwość, z którą przesyłki docierają do odbiorców w zaplanowanym i oczekiwanym czasie (timeliness) [Bentyn 2015, s. 379].

System celny, w którym terytorium Zjednoczonego Królestwa należy do Unii Europejskiej, jest wyjątkowo korzystnym rozwiązaniem ze względu na tempo i koszty operacji logistycznych i handlowych związanych z przepływem towaru. Scenariusz zakładający brak porozumienia w sprawie umowy obowiązującej po ustaniu członkostwa zakłada realizację wersji Brexitu, nazywaną twardym Brexitem (Hard Brexit). Oznacza ona posługiwanie się zasadami Światowej Organizacji Handlu regulującymi wymianę towarową między Zjednoczonym Królestwem a EU. Korporacje międzynarodowe tworzące europejskie łańcuchy dostaw działają dotychczas w systemie, który uwalnia je od płacenia cła pomimo wielokrotnego przekraczania granic państwowych w UE. Brak dodatkowej umowy handlowej UE i Zjednoczonego Królestwa wymusi stosowanie taryfy celnej oraz kontyngentów dla towarów przekraczających granicę [The Economist 2017]. Koszty z tym związane oraz administracyjne obciążenia mogą bezpośrednio spowalniać operacje transportu i pośrednio negatywnie wpływać na operacje magazynowania.

Infrastruktura logistyczna jest obszarem, w którym zagrożenia mogą dotyczyć długiego okresu. Aktualny poziom infrastruktury jest zadowalający i ulegał on poprawie w ostatnim okresie pomiarowym badania Banku Światowego. Jednakże w kolejnych latach udział funduszy Europejskich stanowiących znaczny potencjał w procesie rozbudowy infrastruktury Zjednoczonego Królestwa może zmniejszyć się do tego stopnia, że utrzymanie aktualnego poziomu wydajności będzie bardzo trudne. Przejęcie wydatków inwestycyjnych w tym zakresie przez rządu Zjednoczonego Królestwa będzie konieczne i zadecyduje o utrzymaniu czy też deprecjacji dziś dostępnej infrastruktury logistycznej. Parlament Zjednoczonego Królestwa utrzymuje, że np. finansowanie linii szybkiej kolei HS2 Londyn-Manchester znajdującej się w europejskim korytarzu transportu powstaje z jedynie niewielkim udziałem funduszy unijnych szacowanym na przedział 4-6\% [Butcher 2016]. W konsekwencji Brexitu minimalizuje to ryzyko zatrzymania realizacji projektu.

Organizowanie przesyłek w transporcie międzynarodowym to jedyny obszar wydajności logistycznej, który uległ pogorszeniu od roku 2014. Przyczynami tego stanu mogły być opóźnienia związane z transportem związane z kryzysem emigracyjnym, którego konsekwencje obserwowane są w okolicach portu w Calais. Zjawi- 
sko migracji grożące tymczasowym zamykaniem granic uświadomiło już podmiotom gospodarczym zalety wieloletniego procesu budowy spójnego regionu UE dla wymiany handlowej [Bentyn 2016]. Ponad 50\% międzynarodowego handlu Zjednoczonego Królestwa przypada na handel z krajami UE. Z tej kwoty $40 \%$ jest transportowana drogą morską. Dlatego sytuacja portów handlowych jest szczególnie ważna w perspektywie realizacji Brexitu. Niezależni analitycy ostrzegają, że zmiana kosztów logistycznych może wpłynąć na wielkość i schemat aktywności spedycyjnej w portach. Konieczność kontroli celnych w imporcie i eksporcie prawdopodobnie wywoła kongestię w portach zarówno Zjednoczonego Królestwa, jak i portach na kontynencie [Oxera 2016].

Jakość i kompetencje operatorów logistycznych to dziedzina wysoko oceniana w świetle badań Banku Światowego. Wyjście z UE nie powinno zmienić szczególnie tego parametru wydajności. Jednocześnie pewnym zagrożeniem jest wzrost i utrzymywanie się, przez okres negocjacji umowy handlowej z UE, niepewności dla Brytyjskich firm transportowych. Będzie on spowodowany oczekiwaniem na zmiany w zakresie zatrudnienia pracowników, godzin pracy kierowców, zasad dostępu do rynków krajów UE i oczekiwanych problemów w trakcie kontroli granicznych. Zdolności do śledzenia pojazdów w ruchu kołowym nie ulegną zmianie. Poprawa $\mathrm{w}$ tym zakresie jest zależna od rozwoju technologii i planowanych inwestycji w tym zakresie.

Częstotliwość, z którą przesyłki docierają do odbiorców w zaplanowanym i oczekiwanym czasie z pewnością, wpływają na wydajność logistyczną. Oczekiwanym problemem z powodu Brexitu jest spowolnienie przepływu towarów na granicy [The Lorry Lawyer 2016]. Choć technicznie można przewidzieć tempo przepływu towarów, konsekwencje jego spadku mogą wpłynąć na politykę magazynową wielu firm. Krótkie oczekiwanie na dostawę jest istotnym elementem wysokiego poziomu obsługi logistycznej [Szymczak 2015]. Brak szybkiego dostępu do części, towaru lub surowca utrudnia planowanie i wymusza zwiększanie stanów magazynowych. W szczególności zapasy bezpieczeństwa umożliwiające przedsiębiorstwom kontynuacje procesów technologicznych będą rosły. W efekcie przyniesie to wzrost kosztów magazynowania.

\section{Zakończenie}

Choć obserwowany do roku 2016 dzięki badaniom Banku Światowego wzrost wydajności logistycznej Zjednoczonego Królestwa koreluje ze wzrostem LPI w Europie i Azji Centralnej, wydaje się, że Brexit może zachwiać tą tendencją. Odwrócenie tendencji integracyjnych związanych z pojmowaniem UE jako jednolitego obszaru - wspólnego europejskiego rynku prowadzi nieuchronnie do budowy barier w postaci granicy, cła i przepisów. Bariery takie są niebezpieczne dla nowoczesnych łańcuchów dostaw budowanych jako niskokosztowe i szybko reagujące struktury, konieczne do obsługi logistycznej wysokokonkurencyjnego rynku. Konieczność 
Zbigniew Bentyn

zabezpieczenia operacji technologicznych wymusi zwiększanie poziomów zapasów bezpieczeństwa co przyniesie wzrost kosztów magazynowania.

Konsekwencje Brexitu dla europejskich łańcuchów dostaw są w pewnym zakresie możliwe do przewidzenia. Budowa barier dla przepływu towarów i ludzi w związku z powstaniem granicy w obszarze aktualnej unii celnej spowoduje koszty związane z koniecznością realizacji kontroli granicznych i uiszczania opłat celnych, Ponadto obsługa administracyjna procesu wpłynie na powstanie nowych procedur. Pośrednim efektem tych czynności będzie niskie tempo przepływu towarów przez granicę, co utrudni integrację w europejskich łańcuchach dostaw sięgających powiązaniami na terytorium Zjednoczonego Królestwa.

\section{Literatura}

Bentyn Z., 2015, Przemiany uwarunkowań logistycznych w Polsce jako efekt integracji z krajami Unii Europejskiej, Prace Naukowe Uniwersytetu Ekonomicznego we Wrocławiu, Wydawnictwo Uniwersytetu Ekonomicznego we Wrocławiu, nr 407, Wrocław.

Bentyn Z., 2016, Rozwój obszaru szczególnej aktywności logistycznej w kierunku Europy Środkowo-Wschodniej, [w:] Bentyn Z., Szymczak M. (red), Logistyka i zarządzanie łańcuchem dostaw wobec wyzwań gospodarki światowej, Wydawnictwo UEP, Poznań.

Bentyn Z., 2016, Wpływ przywracania wyjatkowych kontroli granicznych w strefie Schengen na funkcjonowanie europejskich tańcuchów dostaw, Ekonomia XXI Wieku, Economics of the 21st Century, Wydawnictwo Uniwersytetu Ekonomicznego we Wrocławiu, nr 3 (11), s. 207.

Bentyn Z., Majchrzak-Lepczyk J., 2016, Poland as an Example of Economic Development trough Participation in European Supply Chains, [w:] Szymczak M., Rynarzewski T. (red.), Changes and Challenges in the Modern World Economy, Poznań University of Economics and Business Press, Poznań.

Blaik P., 2016, Identyfikacja poziomu kosztów logistyki w skali światowej a ranking logistics performance index (LPI), [w:] Bentyn Z., Szymczak M. (red.), Logistyka i zarzadzanie łańcuchem dostaw wobec wyzwań gospodarki światowej, Wydawnictwo UEP, Poznań.

Butcher L., 2016, Brexit: How will it affect transport?, Briefing Paper, Number CBP7633, House of Commons Library.

Gołembska E., Majchrzak-Lepczyk J., Bentyn Z., 2015, Eurologistyka, PWN, Warszawa.

Gorzelak G., 2012, The Regional Dimension of Transformation in Central Europe, Routledge, London. lpi.worldbank.org (20.05.2017).

Oxera Agenda, 2016, Agenda - Brexit: Implications for the Transport Sector, Oxera Compelling Economics, www.oxera.com (12.04.2017).

Schatzl L., 1993, Wirtschaftsgeographie der Europäischen Gemeinschaft, Uni-TB, Stuttgart.

Supply Chain Media BV, http://www.supplychainmovement.com, 2014.

Szymczak M., 2015, Ewolucja łańcuchów dostaw, Wydawnictwo Uniwersytetu Ekonomicznego w Poznaniu, Poznań.

The Economist, 9.01.2017, Why the "WTO option" for Brexit will prove tricky, www.economist.com (20.05.2017).

The Lorry Lawyer, 2016, Brexit: What Next for the Road Transport Industry?, www.thelorrylawyer. com (20.05.2017).

Van Goor A.R., Ploos van Amstel M.J., Ploos van Amstel W., 2003, European Distribution and Supply Chain Logistics, Stenfert Kroese, Groningen.

Witkowski J., 2010, Zarządzanie tańcuchem dostaw, Wydawnictwo PWE, Warszawa. 